\title{
Protein recycling in Bering Sea algal incubations
}

\author{
Eli K. Moore ${ }^{1, *}$, H. Rodger Harvey ${ }^{1,3}$, Jessica F. Faux ${ }^{1}$, David R. Goodlett ${ }^{2}$, \\ Brook L. Nunn ${ }^{2}$
}

${ }^{1}$ University of Maryland Center for Environmental Science, Chesapeake Biological Laboratory, Solomons, MD 20688, USA ${ }^{2}$ Department of Medicinal Chemistry, University of Washington, Seattle, WA 98195, USA ${ }^{3}$ Department of Ocean, Earth and Atmospheric Sciences, Old Dominion University, Norfolk, VA 23529, USA

\begin{abstract}
Protein present in phytoplankton represents a large fraction of the organic nitrogen and carbon transported from its synthesis in surface waters to marine sediments. Yet relatively little is known about the longevity of identifiable protein in situ, or the potential modifications to proteins that occur during bloom termination, protein recycling and degradation. To address this knowledge gap, diatom-dominated phytoplankton was collected during the Bering Sea spring blooms of 2009 and 2010, and incubated under darkness in separate shipboard degradation experiments spanning 11 and $53 \mathrm{~d}$, respectively. In each experiment, the protein distribution was monited over time using shotgun proteomics, along with total hydrolyzable amino acids (THAAs), total protein, particulate organic carbon (POC) and nitrogen (PN), and bacterial cell abundance. Identifiable proteins, total protein and THAAs were rapidly lost during the first $5 \mathrm{~d}$ of enclosure in darkness in both incubations. Thereafter the loss rate was slower, and it declined further after $22 \mathrm{~d}$. The initial loss of identifiable biosynthetic, glycolysis, metabolism and translation proteins after $12 \mathrm{~h}$ may represent shutdown of cellular activity among algal cells. Additional peptides with glycan modifications were identified in early incubation time points, suggesting that such protein modifications could be used as a marker for internal recycling processes and possibly cell death. Protein recycling was not uniform, with a subset of algal proteins including fucoxanthin chlorophyll binding proteins and $\mathrm{Ru}-$ BisCO identified after $53 \mathrm{~d}$ of degradation. Non-metric multidimensional scaling was used to compare the incubations with previous environmental results. The results confirmed recent observations that some fraction of algal proteins can survive water column recycling and undergo transport to marine sediments, thus contributing organic nitrogen to the benthos.
\end{abstract}

KEY WORDS: Protein recycling $\cdot$ Bering Sea $\cdot$ Amino acid $\cdot$ Nitrogen cycle $\cdot$ Tandem mass spectrometry $\cdot$ Diatom $\cdot$ Cell death $\cdot$ Preservation

\section{INTRODUCTION}

Diatoms typically dominate phytoplankton biomass in many regions of the global ocean, particularly the Bering Sea (Banahan \& Goering 1986, Springer et al. 1996), which is also one of the most productive marine systems in the world (Sambrotto et al. 1986, McRoy et al. 1987). During ice retreat in spring, factors such as rapid diatom production, reduced impact by zooplankton grazing, and the shallow average shelf depth combine to allow a large fraction of new primary production to be transported to sediments (Chen et al. 2003, Lovvorn et al. 2005). Recent work

\footnotetext{
*Corresponding author: rharvey@odu.edu
}

has documented that specific components of cellular material including intact phytoplankton proteins can be transported to shallow shelf and deeper basin sediments in the Bering Sea, confirming the link between primary production and inputs of organic nitrogen to the ocean floor (Moore et al. 2012a). With diatom aggregates estimated to sink at rates of $100 \mathrm{~m}$ $\mathrm{d}^{-1}$ or greater (Smetacek 1985), this raises the question of the kinetics of water column recycling, how long identifiable phytoplankton proteins might be retained, and what fraction of protein material representing exported organic nitrogen is incorporated to sediments and benthic organisms.

() The authors 2014. Open Access under Creative Commons by Attribution Licence. Use, distribution and reproduction are unrestricted. Authors and original publication must be credited. 
In a previous laboratory study, proteins from a pure culture of the marine diatom Thalassiosira pseudonana were observed over $23 \mathrm{~d}$ following exposure in darkness to a natural microbial community (Nunn et al. 2010). While this study demonstrated the potential for preservation of proteins, the greatest loss in the number of identifiable proteins took place during the initial $5 \mathrm{~d}$ darkness period of the $23 \mathrm{~d}$ degradation. This suggests that diatoms may restructure and recycle their proteome in order to acclimate to low light levels, and disable replication pathways during the initial stages of bloom senescence. An examination of the early stage of diatom cell death in natural communities is required to better understand protein cycling prior to microbially catalyzed degradative processes. Proteomic studies on plant programmed cell death (Chivasa et al. 2011, Choi et al. 2011) and algal cell stress (Jamers et al. 2009, Silvestre et al. 2012) have identified potential indicators and regulators of proteomic alteration. In the Bering Sea, ice retreat modulates the highly productive, but temporally constrained spring bloom, which facilitates tracking of potential algal population markers for cell death and subsequently bloom termination.

After bloom termination, sinking phytoplankton material accounts for much of the high organic matter export (Moran et al. 2012). A study of Bering Sea algal material, sinking sediment trap material, and surface sediments collected during the spring phytoplankton bloom found a statistically significant correlation between the number of identifiable proteins and the fraction of particulate nitrogen made up by total hydrolyzable amino acid nitrogen (THAA-N/PN; Moore et al. 2012a). In this study, shipboard incubation experiments using collected natural communities allow the timing of degradation to be observed, revealing which proteins/processes are involved in nitrogen export to sediments. The objectives were to use proteomic and bulk analysis to track changes of newly produced bloom material during its degradation to determine proteome changes, selective preservation, the longevity of individual proteins under more realistic environmental conditions, and thus the fate of a major organic nitrogen pool in the region.

\section{MATERIALS AND METHODS}

\section{Incubations}

Bering Sea water was collected during Bering Sea Ecosystem Study (BEST; Wiese et al. 2012) cruises on the outer shelf during the spring of $2009\left(59.9037^{\circ} \mathrm{N}\right.$, $176.1278^{\circ} \mathrm{W}$; sampling depth $5 \mathrm{~m}$; water column depth $136 \mathrm{~m})$ and $2010\left(56.7272^{\circ} \mathrm{N}, 169.4271^{\circ} \mathrm{W}\right.$; sampling depth $36 \mathrm{~m}$; water column depth $104 \mathrm{~m}$ ) in areas which coincided with the developing spring bloom adjacent to the retreating ice. The phytoplankton community at the time of sampling was diatom dominated (Lomas et al. 2012, Moran et al. 2012). In each year, single 201 carboys were filled from the CTD rosette taken from the chlorophyll maximum based on chlorophyll fluorescence at the time of sampling. In order to increase the amount of algal material for analysis throughout the incubation, 11 of concentrated phytoplankton material was obtained by gently passing 101 of CTD water from an additional bottle through a $10 \mu \mathrm{m}$ mesh and combined with untreated seawater to make up the 201 incubation. Macrozooplankton were excluded from the incubation by passing CTD water through a $1 \mathrm{~mm}$ plankton net before being added to the 201 carboys.

Incubations were placed in shipboard $-1^{\circ} \mathrm{C}$ cold rooms for $11 \mathrm{~d}$ (2009) and $53 \mathrm{~d}$ (2010) for the duration of the experimental period. Carboys were covered to exclude light throughout the incubations and aerated with filtered air. At regular time points, carboys were gently mixed until algal material was homogeneously distributed, and 11 water samples were collected and filtered onto $25 \mathrm{~mm}$ pre-combusted glass fiber filters $(\mathrm{GF} / \mathrm{F})$ and $37 \mathrm{~mm}$ polycarbonate $(0.2 \mu \mathrm{m})$ filters for analysis (Table 1). In addition, whole water samples were collected at each time point and filtered onto $0.2 \mu \mathrm{m}$ filters, DAPI stained, and fixed onto microscope slides for bacterial counts. All incubation particles and bacterial slides were stored at $-70^{\circ} \mathrm{C}$ until analysis or counting. Stained bacterial cells were counted on an Olympus BH2-RFCA fluorescent microscope.

\section{Amino acid and bulk analysis}

Total hydrolyzable amino acids (THAAs) were identified and quantified by gas chromatography/mass spectrometry (GC/MS) using the EZFaast method (Phenomonex), which uses derivatization of amino acids with propyl chloroformate and propanol for detection (Waldhier et al. 2010). Briefly, suspended particles collected on GF/Fs were hydrolyzed for $4 \mathrm{~h}$ at $110^{\circ} \mathrm{C}$ (Cowie \& Hedges 1992) with $6 \mathrm{M}$ analyticalgrade $\mathrm{HCl}$ and $\mathrm{L}-\gamma$-Methylleucine as the recovery standard. Following hydrolyzis and derivatization, amino acids were quantified using an Agilent 6890 capillary GC with samples injected at $250^{\circ} \mathrm{C}$ and separated on a DB-5MS (0.25 mm ID, $30 \mathrm{~m})$ column with 
Table 1. Results of shipboard degradation experiments from $11 \mathrm{~d}$ (2009) and $53 \mathrm{~d}$ (2010) incubations of phytoplankton collected from the Bering Sea: changes over time in the C/N ratio, total hydrolyzable amino acids (THAAs), total protein (Bradford assay), bacterial cell abundance, and total protein identifications (using trypsin, EndoGluC, and PNGase + trypsin). nd: not determined

\begin{tabular}{|c|c|c|c|c|c|}
\hline \multicolumn{6}{|c|}{$11 \mathrm{~d}$ incubation } \\
\hline Day & $\mathrm{C} / \mathrm{N}$ & $\begin{array}{l}\text { THAAs } \\
\left(\mathrm{mg} \mathrm{l}^{-1}\right)\end{array}$ & $\begin{array}{l}\text { Total protein } \\
\qquad\left(\mathrm{mg} \mathrm{l}^{-1}\right)\end{array}$ & $\begin{array}{l}\text { Bacteria } \\
\left(\text { cells } 1^{-1}\right)\end{array}$ & $\begin{array}{l}\text { Total } \\
\text { IDs }\end{array}$ \\
\hline 0 & 3.99 & 1013.00 & 1067.53 & $6.03 \times 10^{7}$ & 127 \\
\hline 0.5 & 3.63 & 448.52 & 618.51 & nd & 48 \\
\hline 1 & 3.77 & 612.73 & 545.53 & $5.60 \times 10^{7}$ & 64 \\
\hline 3 & 3.54 & 571.18 & 680.93 & $1.03 \times 10^{8}$ & 41 \\
\hline 5 & 3.58 & 539.73 & 568.45 & $1.62 \times 10^{8}$ & 51 \\
\hline 7 & 3.56 & 454.31 & 566.94 & $2.10 \times 10^{8}$ & 37 \\
\hline 9 & 3.59 & 424.91 & 386.81 & $2.73 \times 10^{8}$ & 42 \\
\hline 11 & 3.55 & 400.61 & 404.50 & $1.14 \times 10^{8}$ & 39 \\
\hline \multicolumn{6}{|c|}{$53 \mathrm{~d}$ incubation } \\
\hline Day & $\mathrm{C} / \mathrm{N}$ & $\underset{\left(\mathrm{mg} \mathrm{l}^{-1}\right)}{\text { Amino acids }}$ & $\begin{array}{l}\text { Total protein } \\
\qquad\left(\mathrm{mg} \mathrm{l}^{-1}\right)\end{array}$ & $\begin{array}{l}\text { Bacteria } \\
\left(\text { cells } 1^{-1}\right)\end{array}$ & $\begin{array}{l}\text { Total } \\
\text { IDs }\end{array}$ \\
\hline 0 & 4.37 & 805.63 & 988.57 & $7.56 \times 10^{7}$ & 95 \\
\hline 5 & 4.57 & 439.98 & 453.59 & $1.63 \times 10^{8}$ & 32 \\
\hline 12 & 4.47 & 386.44 & 177.42 & $8.90 \times 10^{7}$ & 31 \\
\hline 22 & 4.62 & 337.93 & 233.63 & $7.94 \times 10^{7}$ & 15 \\
\hline 35 & 4.93 & 244.67 & 248.82 & $7.79 \times 10^{7}$ & 13 \\
\hline 47 & 4.96 & 200.72 & 185.55 & $8.04 \times 10^{7}$ & 8 \\
\hline 53 & 4.83 & 178.81 & 295.31 & $7.74 \times 10^{7}$ & 13 \\
\hline
\end{tabular}

$\mathrm{H}_{2}$ as the carrier gas. The oven was ramped from an initial temperature of $110^{\circ} \mathrm{C}$ to $280^{\circ} \mathrm{C}$ at $10^{\circ} \mathrm{C} \mathrm{min}{ }^{-1}$ followed by a 5 min hold. Amino acid identification was accomplished by an Agilent $5973 \mathrm{~N}$ mass spectrometer run under the same conditions with helium as the carrier gas and mass spectral acquisition over the 50 to 600 Da range. The protein bovine serum albumin (BSA) was analyzed in parallel to correct for responses among individual amino acids and calculation of molar ratios. The analytical precision (\% relative standard deviation) for amino acid analysis was $\pm 5 \%$. Amino acids were normalized to percent carbon and nitrogen present in bulk samples analyzed by standard combustion methods. Total protein content was also estimated by the Bradford assay (Bradford 1976).

\section{Preparation for proteomic analysis}

Incubation particles collected on polycarbonate filters were extracted for proteins with pulse sonication in $6 \mathrm{M}$ urea with a Branson 250 sonication probe at $20 \mathrm{kHz}$ for $30 \mathrm{~s}$ on ice. The extracts were then frozen at $-80^{\circ} \mathrm{C}$, thawed, and sonicated again for $30 \mathrm{~s}$ on ice. This was repeated for a total of 5 sonications and 4 freeze/thaw cycles. Filter extracts of each incubation time point were then digested in 3 replicate groups: (1) standard tryptic digestion with reduction and alkylation (Nunn et al. 2010); (2) digestion with Endoproteinase GluC (Endo GluC), which cleaves peptide bonds C-terminal to glutamic acid (Drapeau et al. 1972) and to a lesser extent aspartic acid (Birktoft \& Breddam 1994), to increase the number of proteins identified; and (3), incubation with Peptide N-Glycosidase F (PNGase F), which hydrolyzes nearly all types of $\mathrm{N}$-glycan chains from glycoproteins and glycopeptides (Maley et al. 1989), in order to observe potentially modified proteins prior to tryptic digestion. All digests were concentrated using a speedvac to a volume that gave a final protein concentration of $1 \mu \mathrm{g}$ per $10 \mu \mathrm{l}$ based on measured protein concentrations of filter extracts. The uniform $1 \mu \mathrm{g}$ per $10 \mu \mathrm{l}$ protein concentration ensured that results would not be biased by sampling, or protein concentration differences at different incubation time points.

\section{Mass spectrometry and database searching}

Protein identification of sample digests was performed via shotgun proteomic tandem mass spectrometry (MS ${ }^{2}$; Aebersold \& Mann 2003). Digests were analyzed using full scan (specific mass to charge ratio $[\mathrm{m} / \mathrm{z}] 350-2000)$, followed by gas phase fractionation with repeat analyses over multiple narrow, but overlapping, $\mathrm{m} / \mathrm{z}$ ranges (Yi et al. 2002, Nunn et al. 2006). Mass spectra were evaluated and database searched with an in-house copy of SEQUEST (Eng et al. 1994, 2008). All searches were performed with no assumption of proteolytic enzyme cleavage (e.g. trypsin, Endo GluC) to allow for identification of protein degradation products due to microbial recycling. A fixed modification was set for $57 \mathrm{Da}$ on cysteine and a variable modification of $16 \mathrm{Da}$ on methionine resulting from alkylation and reduction steps, respectively. A variable 1 Da modification was set for asparagine on PNGase F + trypsin digested samples to account for the conversion of asparagine to aspartic acid after cleavage of glycan chains with the use of PNGase F (Plummer et al. 1984), which takes place specifically at the consensus sequence Asn-XxxSer/Thr where Xxx can be any amino acid except proline (Bause \& Hettkamp 1979).

Each tandem mass spectrum generated was searched against a protein sequence database to correlate predicted peptide fragmentation patterns with observed sample ions. Probabilistic scoring of protein identifications employed PeptideProphet and 
ProteinProphet (Keller et al. 2002, Nesvizhskii et al. 2003) with thresholds set at $90 \%$ confidence levels on PeptideProphet and ProteinProphet for positive protein identifications from SEQUEST search results. Mass spectra from all samples were searched against a database containing the proteomes of Thalassiosira pseudonana (marine diatom), Prochlorococcus marinus (marine cyanobacterium), and Candidatus Pelagibacter ubique (marine bacterium belonging to the SAR11 clade). These proteomes were selected to follow protein degradation in a diatom dominated system with potential input of bacterial proteins (e.g. Nunn et al. 2010). Results of database comparison studies showed functional agreement for over $95 \%$ of identified peptides between the T. pseudonana P. marinus - Ca. P. ubique database versus the larger NCBI non-redundant database containing over 11 million protein sequences (Moore et al. 2012b). To better compare shipboard incubations with previous field observations, non-metric multidimensional scaling (NMDS, theory and applications described in Borg \& Groenen 2005), was performed using R statistical software to group incubation time points with Bering Sea water column particles and surface sediments from a previous study (Moore et al. 2012a), based on the distribution of identified proteins in each sample. Suspended water column particles, sinking sediment trap material, and surface sediments analyzed by Moore et al. (2012a) were collected before, during, and after the spring 2009 phytoplankton bloom and analyzed using the same proteomic methods as samples from experimental incubations.

\section{RESULTS}

Algal proteins, identified as originating from diatoms resembling those of the proteome from Thalassiosira pseudonana, were detected throughout both incubations for as long as $53 \mathrm{~d}$ (Table 1, Fig. 1A). In the $11 \mathrm{~d}$ incubation, there was a rapid loss among identifiable proteins in the first $0.5 \mathrm{~d}$ after the onset of darkness, followed by a slower rate of loss after $1 \mathrm{~d}$. In the longer $53 \mathrm{~d}$ incubation, there was a rapid loss of identifiable proteins in the first $5 \mathrm{~d}$. The rate of loss slowed thereafter and the number of identified proteins remained relatively constant after $22 \mathrm{~d}$. Similar trends were observed in both incubations for THAAs (Fig. 1B) and total protein (Fig. 1C). The THAA distribution was fairly consistent among the 11 and $53 \mathrm{~d}$ incubations (Appendix 1), with a sharp drop in alanine from the start $(0 \mathrm{~h})$ to the $12 \mathrm{~h}$ time point in the
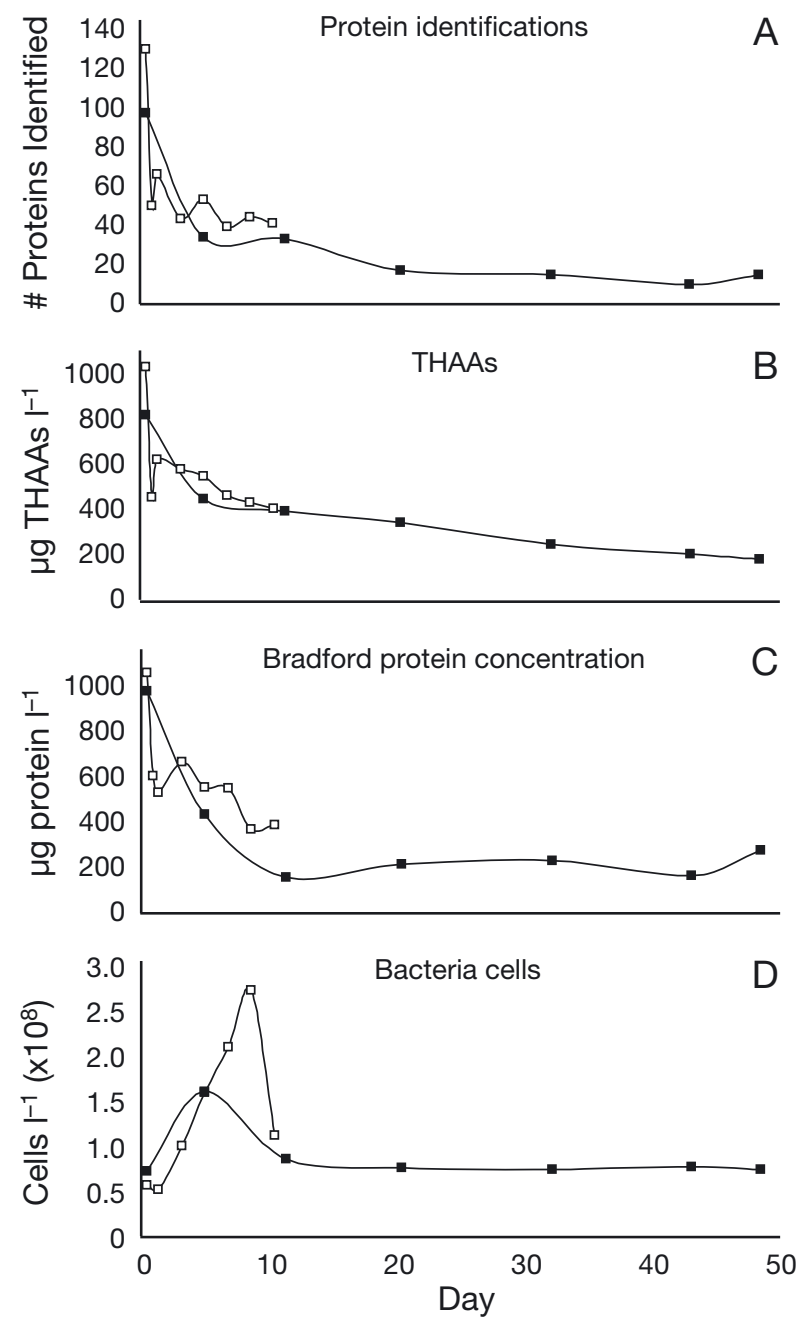

Fig. 1. Changes over time during () $11 \mathrm{~d}$ (2009) and (ロ) $53 \mathrm{~d}$ (2010) incubations of phytoplankton collected from the Bering Sea in (A) total protein identifications; (B) total hydrolyzable amino acids (THAAs); (C) total protein (Bradford assay); (D) bacterial cell abundance

$11 \mathrm{~d}$ incubation, and a spike in glutamic acid/glutamine at Day 22 of the $53 \mathrm{~d}$ incubation. Total bacterial abundance peaked within the first $9 \mathrm{~d}$ of both incubations and declined thereafter (Fig. 1D). Despite the rapid increase in bacterial abundance, only 3 and 2 specific prokaryotic proteins were identified over the course of the 11 and $53 \mathrm{~d}$ incubations respectively.

Among the suite of proteins observed during the degradation sequence, chloroplast and secretory proteins were the 2 major cellular compartments represented by identified proteins in both incubations, with smaller contributions of proteins from the mitochondria, nucleus, ribosome, and unknown compartments (Fig. 2). As the incubation progressed, the sequence coverage of identified proteins generally decreased in tandem with the number of identified 


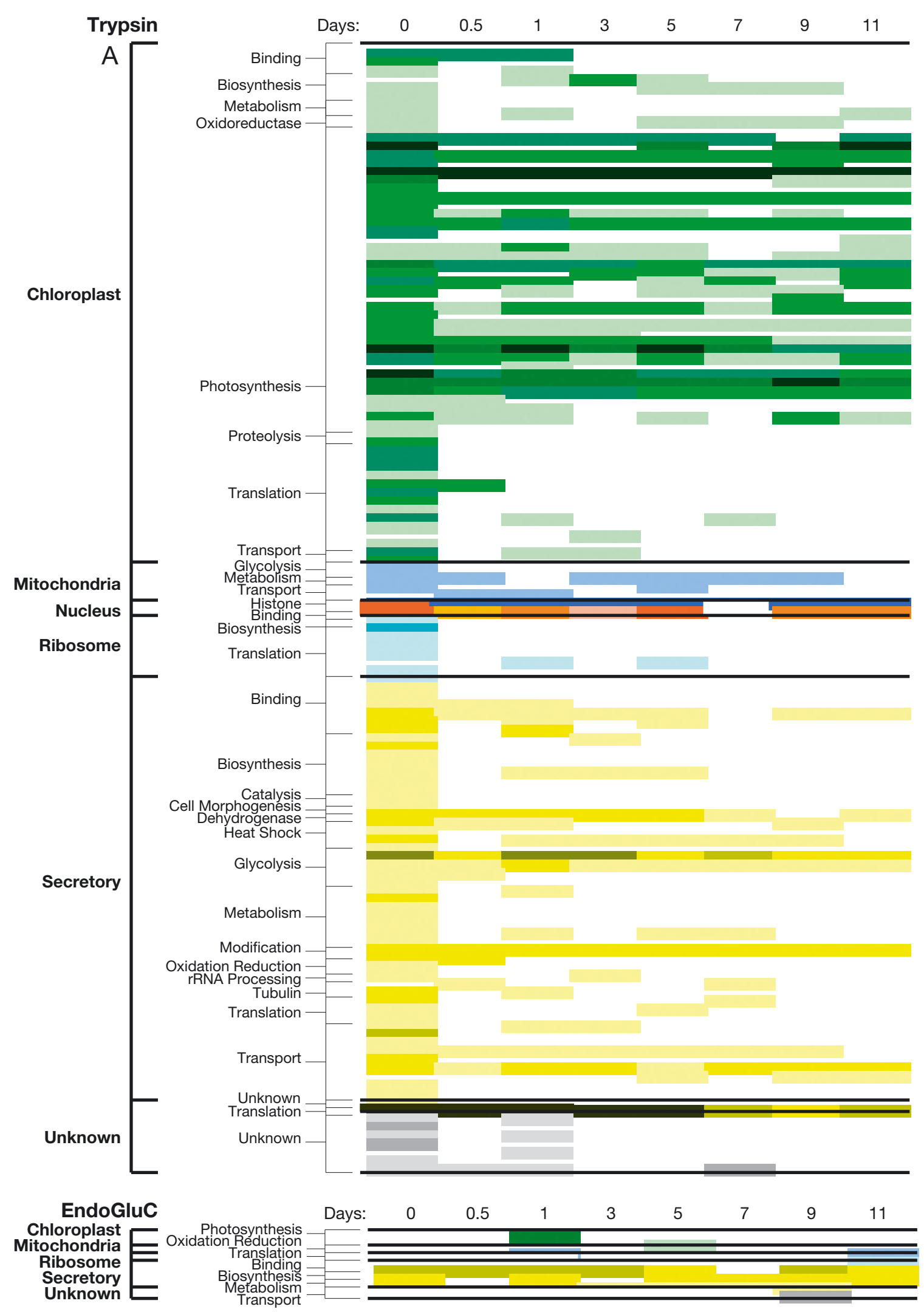

Fig. 2. Proteins identified in incubations at each time point analyzed, organized by compartment and function, showing trypsin and EndoGluC identifications for (A) $11 \mathrm{~d}$ and (B, next page) $53 \mathrm{~d}$ incubations. Cellular compartments are differentiated by color, with individual protein sequence coverage (\%) represented by shading, as shown in the key 


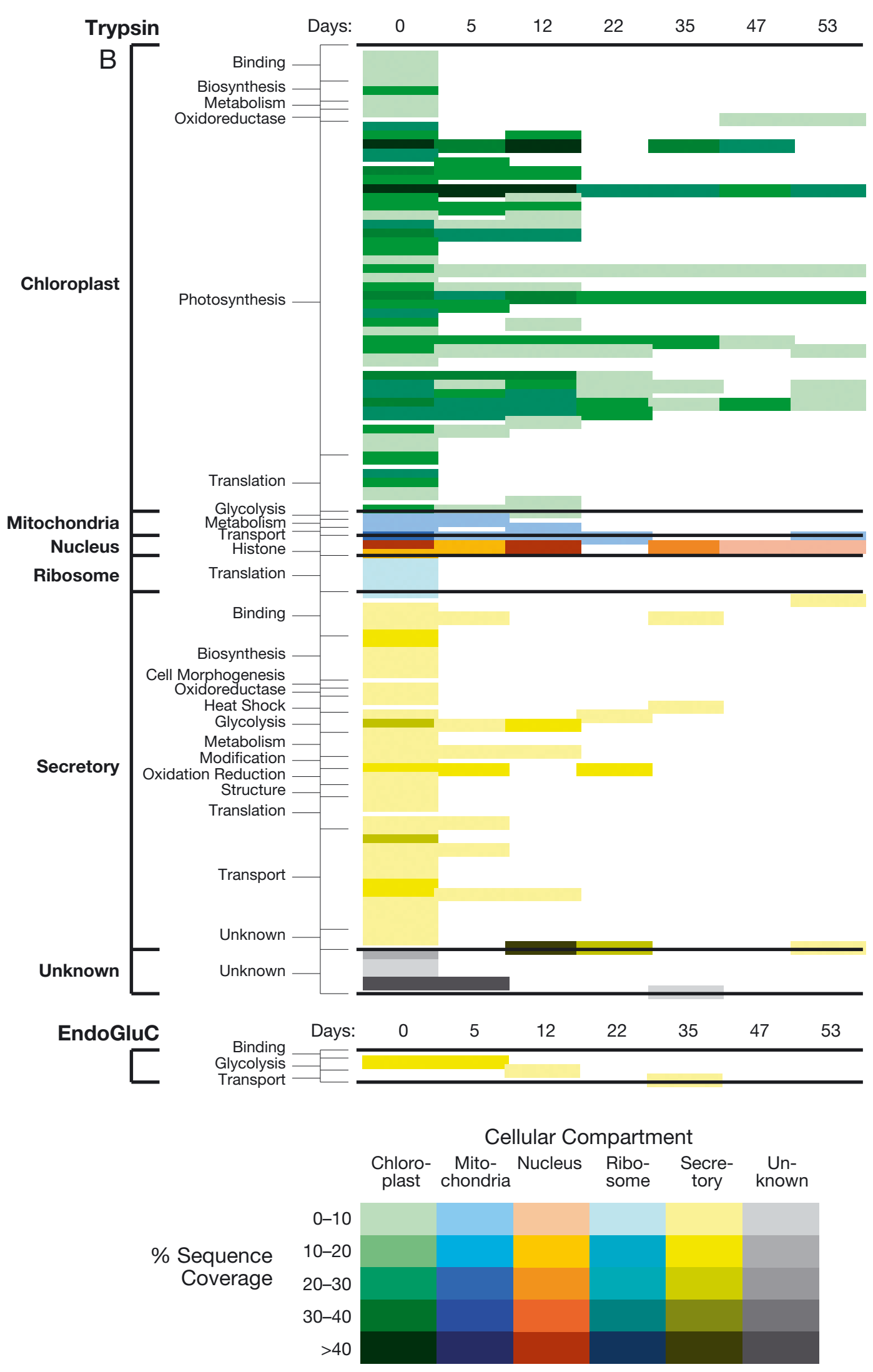

Fig. 2 (continued) 
proteins. Chloroplast proteins were the most persistent, increasing in relative abundance from $44 \%$ and $48 \%$ of total proteins at Day 0 to 74 and $67 \%$ in the final time points of the 11 and $53 \mathrm{~d}$ incubations respectively. Conversely, the combined proportion of biosynthesis, glycolysis, metabolism, and translation proteins dropped from $38 \%$ and $27 \%$ at Day 0 to $15 \%$ and $0 \%$ percent at the final time points of the 11 and $53 \mathrm{~d}$ incubations, respectively.

The most dramatic loss of proteins from a specific functional group was observed among translational proteins. Of the 23 translation proteins identified in Day 0 of the $11 \mathrm{~d}$ incubation only 8 were identified in time points beyond Day 0, and none were identified after Day 7. Of the 15 translation proteins identified at Day 0 in the $53 \mathrm{~d}$ incubation only 3 were identified in time points after Day 0, and none were identified after Day 12. Furthermore, only 4 secretory proteins, which might be expected to be more available for microbial recycling than compartmentalized chloroplast proteins, were identified after Day 22. Of the 11 proteins identified at Day 53 of the long incubation, 7 were located in the chloroplast.

The use of PNGase F to lyse glycosidic bonds allowed the identification of several modified peptides, which appeared during the most rapid loss of total identifiable proteins. Two modified peptides were observed in the $11 \mathrm{~d}$ incubation, and 3 modified peptides were observed in the $53 \mathrm{~d}$ incubation. These peptides contained the consensus sequence of AsnXxx-Ser/Thr (Table 2). Such modified peptides were only observed in the first $5 \mathrm{~d}$ of both incubations. The unmodified tryptic version of the peptide from ATP synthase CF0 B chain subunit I, an important component in ATP production, was observed in the same PNGase F + trypsin digest as the modified form at Day 5 of the $53 \mathrm{~d}$ incubation (Table 2). Inspection of the $\mathrm{MS}^{2}$ fragmentation spectra of each peptide showed the mass change on b-ions that contained the altered asparagine for the modified peptide (Fig. 3A,B).

Digestion by EndoGluC also resulted in additional protein identifications: 8 in the $11 \mathrm{~d}$ incubation and 3 in the $53 \mathrm{~d}$ incubation (Fig. 2A,B). The use of EndoGluC on extracted protein yielded 4 additional identifications at Days 1, 5, 9, and 11 in the $11 \mathrm{~d}$ incubation. Over the course of the $53 \mathrm{~d}$ incubation no more than one additional protein was identified using EndoGluC at any time point. Secretory proteins made up the majority of additional protein IDs using the EndoGluC treatment. There were no common protein IDs made using both PNGase F and EndoGluC that were not already identified using trypsin alone.

In the NMDS analysis, early incubation time points (Days 0 to 11 ) cluster closely together, as do later incubation time points (Days 22 to 53). Chl-max particles and sinking sediment trap particles are positioned more closely to initial incubation time points than later time points in the 11 and $53 \mathrm{~d}$ incubations. The post-bloom shelf surface sediment is positioned closer to early incubation time points while post-bloom basin sediment and over wintered shelf sediment are equidistant to intermediate and later incubation time points. It should be emphasized that results of NMDS analysis of shipboard incubations and Bering Sea suspended particles, sinking sediment trap material and surface sediments are qualitative in nature. Samples that are ordinated closer together have protein distributions that are more similar than samples that are ordinated farther apart (Fig. 4). Similar ordinations between incubation time points and water particles or sediments could allow approximate time frame estimations to be assigned to samples in the field.

Table 2. Peptides identified with the amidase PNGase F + the proteolytic enzyme trypsin during $11 \mathrm{~d}(2009)$ and 53 d (2010) incubations of phytoplankton collected from the Bering Sea. Each of these individual peptides contain the 1 Da mass increase on asparagine resulting in the $115 \mathrm{Da}$ aspartic acid (indicated by: $\mathrm{N}[115]$ ), which represents the presence of an N-glycan chain post translational modification on the peptide. The protein to which the peptides were correlated, and the first day of the incubation on which the protein was identified are also given

\begin{tabular}{|c|c|c|}
\hline Protein & Peptide(s) & Day \\
\hline \multicolumn{3}{|l|}{11 d incubation } \\
\hline RuBisCO large subunit & IHYLGDDVVLQFGGGTIGHPDGIQAGATAN[115]R & 1 \\
\hline Predicted protein & DLAEIWDN[115]SSPVIVQGGSLR & 1 \\
\hline \multicolumn{3}{|l|}{$53 \mathrm{~d}$ incubation } \\
\hline RuBisCO large subunit & TALDLWKDISFN[115]YTSTDTADFAETATANR & 0 \\
\hline ATP synthase CF0 B chain subunit I & ALIN[115]ETIQKLEGDLL & 5 \\
\hline Predicted protein & QVVELYTEDGLDRPFFAIVETPGSGN[115]VVR & 5 \\
\hline
\end{tabular}




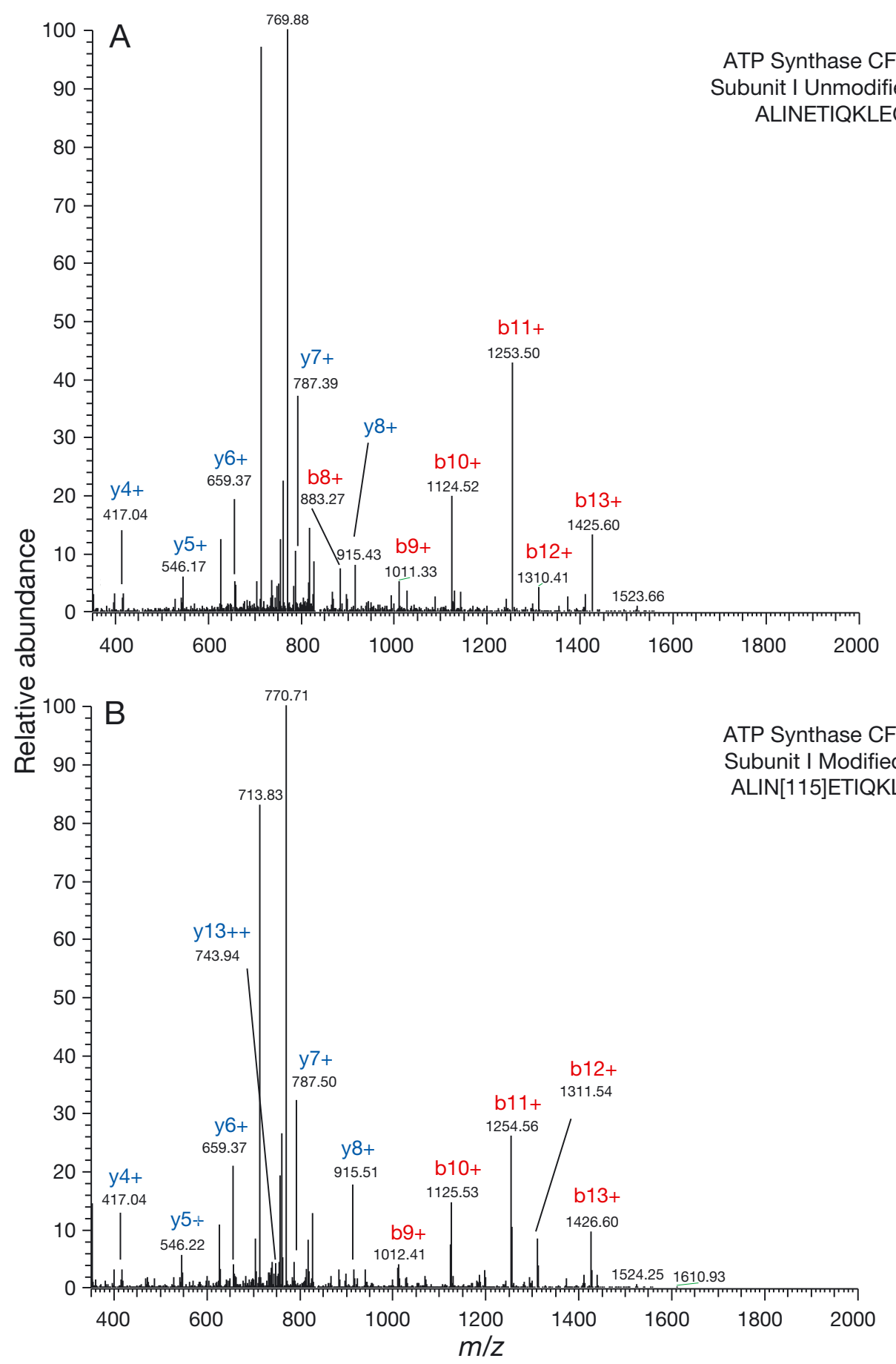

Fig. 3. $\mathrm{MS}^{2}$ spectra of ATP Synthase CF0 B chain subunit I peptide ALINETIQKLEGDLL showing peptide fragment $b$ - and y-ions of the (A) unmodified and (B) modified peptide. The b-ions 9 to 13 are all 1 Da greater in the modified peptide mass spectra, representing the modified asparagine, (e.g. unmodified b11 = ALINETIQKLE; modified b11 = ALIN[115]ETIQKLE)

\section{DISCUSSION}

\section{Differential recycling of algal proteins and preservation}

The survival of algal proteins over $53 \mathrm{~d}$ of microbial recycling demonstrates that some fraction of intact proteins can survive microbial recycling long enough to be exported from the marine water column to sedi- ments. At a sinking rate of up to $100 \mathrm{~m} \mathrm{~d}^{-1}$ (Smetacek 1985), the incubation period of $53 \mathrm{~d}$ is more than adequate for algal proteins in a diatom-dominated system to transit the water column to Bering Sea shelf and basin sediments. The presence of such proteins in sediments was previously observed by Moore et al. (2012a), suggesting that other diatom-dominated ecosystems have the potential for export of identifiable protein from phytoplankton blooms to the sediment. 
Fig. 4. Non-metric multidimensional scaling (NMDS) ordination based on the protein distribution of Bering Sea water column and sediment samples (Moore et al. 2012a) and the time points of the $11 \mathrm{~d}$ and $53 \mathrm{~d}$ incubations: P4: Chl Max suspended particles; P50: $50 \mathrm{~m}$ suspended particles; P100: $100 \mathrm{~m}$ suspended particles; T40: $40 \mathrm{~m}$ sediment trap; T60: $60 \mathrm{~m}$ sediment trap; T100: 100 m sediment trap; PBS: Post-bloom shelf sediment; PBB: Post-bloom basin sediment; OWS: Overwintered shelf sediment; S0, S0.5, S1, S3, S5, S7, S9, S11: 11 d incubation on Days $0,0.5,1,3,5,7,9$ and 11 , respectively; L0, L5, L12, L22, L35, L47, L53: 53 d incubation on Days 0, 5, 12, 22, 35, 47 and 53 , respectively

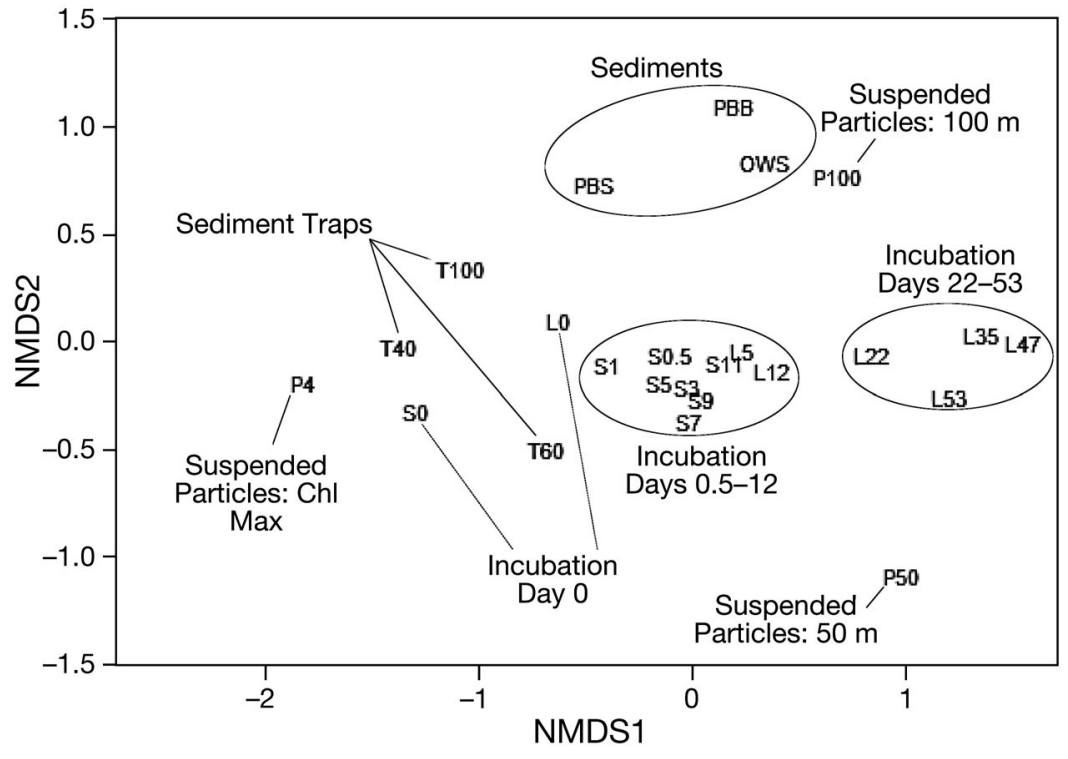

chloroplast proteins, but identified translation proteins located in the chloroplast were lost just as rapidly as translation proteins located in the ribosome or cytoplasm. In previous studies it has been observed that proteins encapsulated in organic matter or cellular compartments are preferentially preserved during microbial recycling (Nguyen et al. 2003, Nunn et al. 2010, Moore et al. 2012a). Cell lysis may have played a role in the loss of cytoplasmic translation proteins, but the rapid loss of identifiable translation proteins with additional membrane protection in cellular compartments indicates that some loss was due to internal recycling within the cell in tandem with microbial activity.

After initial cellular recycling, further changes to protein distribution were observed during microbial recycling as biosynthesis, glycolysis, metabolism, and translation proteins continued to decline until Day 22 and were no longer detectable at the conclusion of the $53 \mathrm{~d}$ incubation. However abundant photosynthetic proteins persisted and remained detectable after $53 \mathrm{~d}$ of degradation (Fig. 2). After 53 d, 5 and 3 peptides were identified from the RuBisCO large and small subunits respectively, contrary to previous findings that RuBisCO was degraded rapidly and not retained in a lab based degradation of Thalassiosira pseudonana (Nunn et al. 2010). Two fucoxanthin chlorophyll binding proteins (FCPs) were identified throughout the $53 \mathrm{~d}$ incubation in agreement with findings that these proteins remain identifiable for extended periods in lab degradation (Nunn et al. 2010), Bering Sea shelf sediments (139 m), and Bering Sea basin sediments (3490 m) (Moore et al. 2012a). plasm proteins was more rapid than the loss of 


\section{Microbial input}

At early time points in both incubations, protein IDs, THAAs, and total protein decreased followed by increases in bacterial cell numbers. The increase in bacterial abundance was first apparent at Day 3 of the $11 \mathrm{~d}$ incubation and continued until Day 9, indicating that there is a slight lag in cell replication after the initial recycling of particulate THAAs, total protein measured spectrophotometrically, and identifiable proteins (Fig. 1). Protein IDs, THAAs, and total protein subsequently decrease more slowly after bacterial cells return to original levels (Fig. 1). Grazing by bacterivores, such as flagellates, protists, and viral lysis (Steward et al. 1996, Vaque et al. 2008) may have decreased bacteria cell counts after initial bacterial proliferation. This would limit overall bacteria-driven protein recycling in later incubation time points. Despite this, bacteria in these incubations appear to be the primary protein recyclers given that macrozooplankton were excluded in these incubations. Using an average bacterial protein content per cell of $24 \mathrm{fg} \mathrm{cell}^{-1}$ (Zubkov et al. 1999), the estimated bacterial fraction of total protein and THAAs was highest at or near the peak bacteria cell abundance in both the 11 and $53 \mathrm{~d}$ incubations (Table 1), but never exceeded $2 \%$ of total protein or THAAs throughout the incubations. This low value for what is also expected to be a large suite of different bacterial protein types may explain why identifiable proteins were dominated by diatom sources and few prokaryotic proteins were observed.

\section{Identifying modified proteins}

While difficulties are common in recognizing protein modifications, identification of such modifications by proteomic methods has the potential to more fully characterize degraded and modified proteins in environmental samples. Non-enzymatic glycation is a major cause of spontaneous damage to cellular and extracellular proteins in physiological systems (Ahmed \& Thornalley 2007). Glycation of RuBisCO has been shown to decrease the enzyme's activity, and increase its susceptibility to proteases (Yamauchi et al. 2002). Various mechanisms have been observed in higher plants (Kim \& Kim 2003, Sultana et al. 2009) and the microalga Chlorella zofingiensis (Sun et al. 2011) to prevent and repair protein glycation. Thus, the potential glycation of RuBisCO and other proteins (Table 2) in the early stages of recycling may represent protein turnover within the cell.
Glycation has also been hypothesized as a mechanism for extra-cellular protein preservation and the formation of sedimentary geopolymers (Collins et al. 1992, Burdige 2007). Mass spectral analysis with InsPecT (Tanner et al. 2005) was used to identify recurring modification masses on precursor ions, revealing potential sugar modifications to proteins from degraded phytoplankton (Nunn et al. 2010). All modified peptides in this study were observed during the early stages of both incubations while the number of observed biosynthesis, glycolysis, metabolism, and translation proteins decreased. While the $5 \mathrm{~d}$ time period over which modified peptides were seen does not allow unequivocal evidence that the observed peptide modifications and proteome changes were directly linked to cell death, (e.g. Peters \& Thomas 1996), such changes may be the initial steps that take place before dormancy and eventually cell death (Bidle \& Falkowski 2004, Nunn et al. 2010).

\section{Identifiable protein correlates to organic matter degradation proxies}

The ratios of THAA/OC and THAA-N/PN can be useful proxies for degradation status of organic matter (Cowie \& Hedges 1994 and references therein). Plotting the number of identified proteins against the ratio of THAA/OC and THAA-N/PN (Fig. 5), reveals that proteins throughout the $11 \mathrm{~d}$ incubation and the 3 earliest time points of the $53 \mathrm{~d}$ incubation (Days $0,5,12$ ) have greater numbers of protein IDs and higher ratios of THAA/OC and THAA-N/PN than samples over longer incubation times of the $53 \mathrm{~d}$ incubation (Days 22, 35, 47, 53), which cluster together more closely. The shift in the number of identified proteins in the $11 \mathrm{~d}$ incubation and early time points of the $53 \mathrm{~d}$ incubation to the cluster of 4 final time points of the $53 \mathrm{~d}$ incubation suggests that, after initial rapid degradation, identifiable protein material degrades much more slowly.

There are significant correlations between the number of protein identifications and both the ratios of THAA/OC and THAA-N/PN (Fig. 5) as observed in suspended particles, sinking material, and surface sediments in the Bering Sea (Moore et al. 2012a). In comparing our shipboard incubations to field collected material from the same location (Moore et al. 2012a), it is striking that the number of identified proteins and ratios of THAA/OC and THAA-N/PN for incubations times of $22,35,47$, and $53 \mathrm{~d}$ were very similar to those seen in deep basin sediments $(3490 \mathrm{~m})$, over wintered shelf sediments $(101 \mathrm{~m})$, and 
Fig. 5. Plots of total protein identifications plotted against the organic matter degradation status parameters, for $(\diamond) 11 \mathrm{~d}$ and $(\diamond)$ $53 \mathrm{~d}$ incubations, showing fraction of (A) organic carbon made up by total hydrolyzable amino acids (THAA/OC); and (B) particulate nitrogen made up by total hydrolyzable amino acid nitrogen (THAAN/PN). Linear regressions represent the correlation between identifiable proteins and organic matter recycling

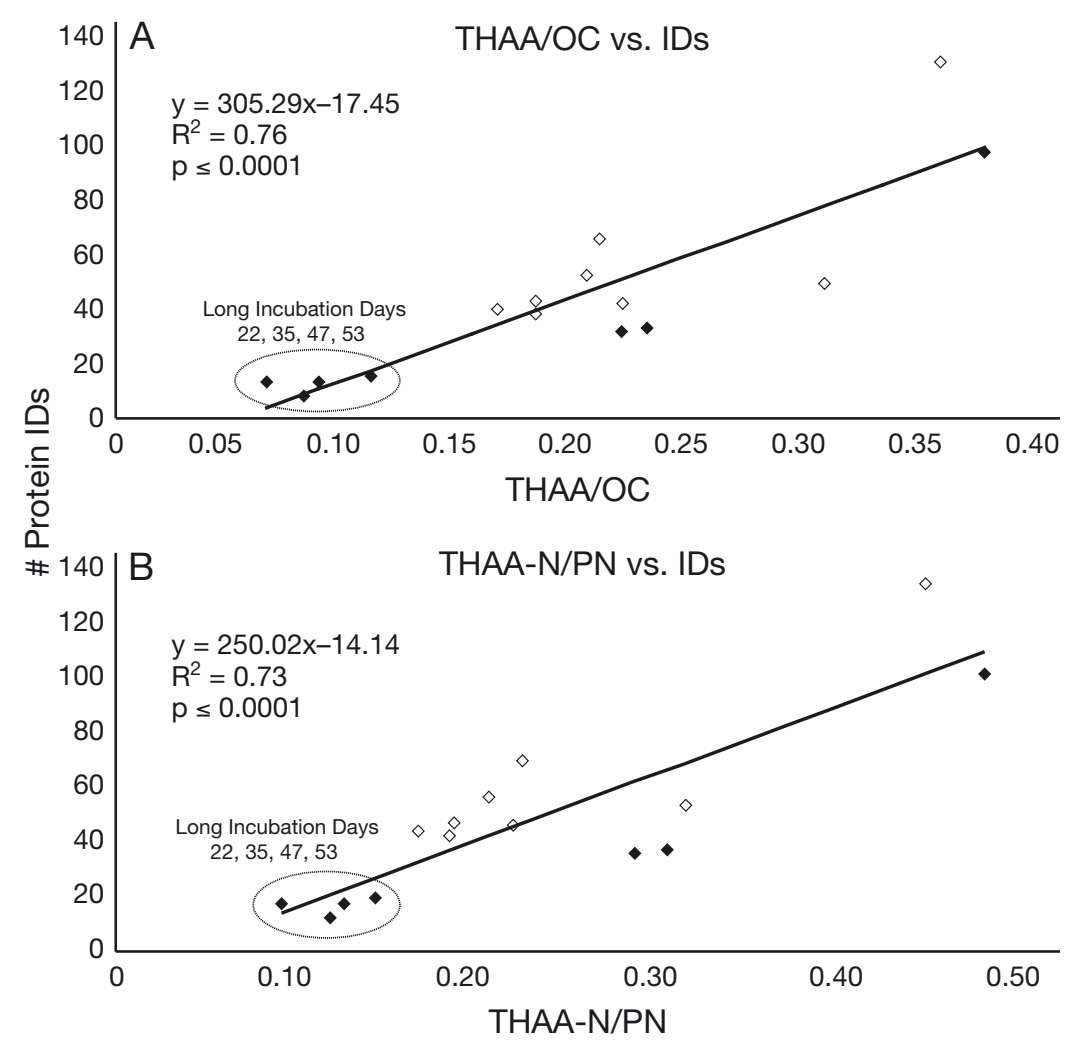

suspended particles (50 m, $100 \mathrm{~m}$ ) of the Bering Sea. Although this finding suggests that the rapid protein losses seen in shipboard incubations are realistic, it also supports findings that intact proteins contribute to a fraction of marine sedimentary amino acids (Pantoja \& Lee 1999, Nguyen \& Harvey 2001, Nunn et al. 2010, Moore et al. 2012a). The distribution of remaining proteins observed after $22 \mathrm{~d}$ also indicates that abundant chloroplast proteins make up the majority of identified preserved proteins.

Amino acids are known to be important contributors to particulate and sedimentary marine nitrogen pools (Burdige \& Martens 1988, Lee et al. 2000). Analysis by ${ }^{15} \mathrm{~N}$ nuclear magnetic resonance (NMR) has also shown that most organic nitrogen present in dissolved and particulate organic matter is amide linked, like the bonds that connect amino acids in proteins (McCarthy et al. 1997, Zang et al. 2001). The correlations between protein IDs, THAA/OC and THAA-N/PN, and the longevity of identifiable protein observed in this study, and in findings by Moore et al. (2012a) identifying algal proteins in Bering Sea sinking sediment trap material and sediments, suggest that diatom dominated systems are important regions of organic nitrogen and organic carbon export. These studies also show promise for proteomic characterization of amide linked nitrogen or protein material measured as THAAs throughout sediments of the global ocean.

\section{Statistical analysis of incubations with environmental samples}

Inspection of the identified protein pool among sediment samples and later incubation time points with NMDS, taking into account protein function, shows evidence that the distribution of proteins identified in post-bloom shelf sediment (Moore et al. 2012a) matches more closely with incubation time points from 0.5 to $12 \mathrm{~d}$ than incubation time points after 22 d (Fig. 4). Proteins identified at later time points of the $53 \mathrm{~d}$ incubation were also identified in post bloom shelf sediment, but they make up only $23 \%$ of identifications. The distribution of identified proteins at time points after $22 \mathrm{~d}$ of the $53 \mathrm{~d}$ incubation matches more closely with post-bloom basin sediment and overwintered shelf sediment in which proteins identified after 22 d make up $38 \%$ and $52 \%$ of identified proteins, respectively. The distribution of common proteins between later time points, postbloom basin, and overwintered shelf sediment includes primarily chlorophyll binding proteins, photosystem II proteins, and DNA binding histones. This 
provides further evidence that protein material which lasts beyond the apparent $22 \mathrm{~d}$ threshold represents material that can be preserved on seasonal timescales and be available as a food source to the benthic community, not only during the productive spring bloom, but the ice-covered winter months as well. The observation that 50 and $100 \mathrm{~m}$ suspended particles are positioned closer to later time points than post-bloom shelf sediment illustrates the importance of export to sediments towards removal from water column recycling and protein preservation.

\section{Implications for benthic communities and the nitrogen cycle}

Given the reduced impact of microbial recycling following $22 \mathrm{~d}$ of incubation on protein IDs, THAAs, total protein, and the similar ratios seen in THAA/OC and THAA-N/PN after $22 \mathrm{~d}$ with Bering Sea sediments, it is reasonable to consider that incubation material after $22 \mathrm{~d}$ is representative of primary production arriving at the sea floor after bloom termination. Approximately $42 \%$ of THAAs remain after $22 \mathrm{~d}$ of microbial recycling compared to initial amounts in the $53 \mathrm{~d}$ incubation. This is a substantial fraction of organic nitrogen available to fuel benthic activity. Therefore, the transport of algal proteins from the water column to sediments indicates that primary production is an important organic nitrogen source to benthic communities. Recycling by consumers may reduce the amount of identifiable proteins in sinking sediment trap material compared to bloom material as observed by Moore et al. (2012a), but grazing impact is reduced during periods of high production (Chen et al. 2003, Lovvorn et al. 2005). This agrees with previous findings that production from the water column supports high benthic faunal density in the Bering Sea (Grebmeier et al. 1988).

The contribution of intact protein to marine sediments may also explain why similar $\delta^{15} \mathrm{~N}$ values have been observed between water column material and surface sediments from the Bering Sea shelf during ice covered winter months (Lovvorn et al. 2005), and in time series samples from coastal upwelling regions of the NE Pacific (Altabet et al. 1999). Furthermore, the longevity of exported phytoplankton proteins to the continental shelf and basin may be important in providing a food source to benthic filter feeders during the ice-covered low production winter months when new material is not being actively exported to sediments. This suggests that protein preservation plays a role in the yearlong ecosystem support of
Bering Sea, and potentially other high latitude coastal, benthic communities.

Global calculations of marine nitrogen fixation and denitrification have estimated a fixed nitrogen deficit of roughly $200 \mathrm{Tg} \mathrm{N} \mathrm{yr}{ }^{-1}$ (Mahaffey et al. 2005, Codispoti 2007). Sedimentary $\delta^{15} \mathrm{~N}$ records however, have suggested global $\mathrm{N}$ cycle homeostasis during the Holocene (Deutsch et al. 2004, Altabet 2007). A more recent study by Großkopf et al. (2012) has shown that a widely used method for measuring $\mathrm{N}_{2}$ fixation rates underestimates the contribution of nitrogen fixing diazotrophs compared to a newly developed method. This results in a nitrogen fixation increase of 103 to $177 \pm 8 \mathrm{Tg} \mathrm{N} \mathrm{yr}^{-1}$ leaving a remaining fixed nitrogen deficit of 23 to $97 \mathrm{Tg} \mathrm{N} \mathrm{yr}^{-1}$. The $2 \mathrm{yr}$ spring summer study by Horak et al. (2013) suggested that denitrification rates in Bering Sea shelf sediments are higher than previously thought, and that sediment regenerated $\mathrm{NH}_{4}{ }^{+}$is an insignificant contribution to water column dissolved inorganic nitrogen (DIN) and primary production. Coupled nitrification-denitrification observed by Granger et al. (2011) has also indicated that $\mathrm{N}$ loss occurring in Bering Sea sediments is greater than other regions of the ocean and that offshelf waters potentially contribute nitrate to the outer shelf. This study presents evidence suggesting that exported protein material from the Bering Sea water column to sediments, where it is denitrified, may also be an important potential pathway for loss of fixed nitrogen transported to the Bering Sea from off shelf, thus contributing to the fixed nitrogen deficit.

\section{CONCLUSIONS}

The persistence of algal proteins during both shortterm and extended shipboard incubation degradation experiments indicates that some fraction of this material can survive water column recycling in timeframes that are amenable to being transported to marine sediments. The initial changes to the distribution of identified translation, biosynthesis, glycolysis, and metabolism proteins indicate that internal cellular recycling plays an important role in protein cycling during the early time points of simulated bloom termination. Glycation modifications were only observed during the first $5 \mathrm{~d}$ of the 2 incubations, suggesting these modifications may be linked with the shutdown of cellular machinery. Continued rapid loss of secretory proteins during the period of bacterial cell population growth represents the microbial recycling of bioavailable proteins that are not encapsulated in cellular compartments and re- 
leased during cell lysis. The number of identifiable proteins, THAAs, total protein, and the ratios of THAA/OC and THAA/PN declined more slowly after $22 \mathrm{~d}$. Identifiable proteins that survived after the observed $22 \mathrm{~d}$ threshold appear to represent material that can be preserved over seasonal timescales in sediments, and be available as a food source to the benthic community. The large fraction of remaining THAAs after initial microbial recycling, and correlations between identifiable proteins and the ratios of THAA/OC and THAA/PN, suggest that identifiable algal proteins make up an important fraction of marine sedimentary organic nitrogen. The observed longevity of identifiable proteins during simulated bloom termination and microbial recycling suggests that diatom dominated systems are important regions for organic nitrogen export and potential preservation in sediments.

Acknowledgements. This work was supported by National Science Foundation (NSF) grant through the Chemical Oceanography Program to H.R.H. (OCE-0825811), D.R.G. and B.L.N. (OCE-0825790, OCE-1233014) with samples obtained as part of the NSF Bering Ecosystem Study Program (BEST) to H.R.H. (ARC-0732667). Computational analysis was conducted on National Institute of Health sponsored computer cluster awards to D.R.G. (1S10RR023044-01, 1U54AI57141-01). We thank Rachel Pleuthner for help conducting the degradation experiments and Megan Bernhardt for preparation of microscope slides. This is MOGEL-OEAS contribution No. 2011-3 of Old Dominion University.

\section{LITERATURE CITED}

Aebersold R, Mann M (2003) Mass spectrometry-based proteomics. Nature 422:198-207

Ahmed N, Thornalley PJ (2007) Advanced glycation endproducts: What is their relevance to diabetic complications? Diabetes Obes Metab 9:233-245

Altabet MA (2007) Constraints on oceanic N balance/imbalance from sedimentary ${ }^{15} \mathrm{~N}$ records. Biogeosciences 4 : 75-86

Altabet MA, Pilskaln C, Thunell R, Pride C, Sigman D, Chavez F, Francois R (1999) The nitrogen isotope biogeochemistry of sinking particles from the margin of the Eastern North Pacific. Deep-Sea Res I 46:655-679

Amon RMW, Benner R (1996) Bacterial utilization of different size classes of dissolved organic matter. Limnol Oceanogr 41:41-51

Banahan S, Goering J (1986) The production of biogenic silica and its accumulation on the southeastern Bering Sea shelf. Cont Shelf Res 5:199-213

Bause E, Hettkamp H (1979) Primary structural requirements for N-glycosylation of peptides in rat liver. FEBS Lett 108:341-344

Bidle KD, Falkowski PG (2004) Cell death in planktonic, photosynthetic, microorganisms. Nat Rev Microbiol 2: 643-655
Birktoft JJ, Breddam K (1994) Proteolytic enzymes: serine and cysteine peptidases. In: Barrett AJ (ed) Methods in enzymology, Vol. 244. Academic Press, San Diego, CA, p 114-126

Borg I, Groenen P (2005) Modern multidimensional scaling: theory and applications, $2^{\text {nd }}$ edn. Springer, New York, NY, p 201-212

Bradford MM (1976) A rapid sensitive method for the quantitation of microgram quantities of protein utilizing the principle of protein-dye binding. Anal Biochem 72: 248-254

Burdige DJ (2007) Preservation of organic matter in marine sediments: controls, mechanisms, and an imbalance in sediment organic carbon budgets? Chem Rev 107: 467-485

Burdige DJ, Martens CS (1988) Biogeochemical cycling in an organic-rich coastal marine basin: 10. The role of amino-acids in sedimentary carbon and nitrogen cycling. Geochim Cosmochim Acta 52:1571-1584

Chen M, Huang YP, Cai PG, Guo LD (2003) Particulate organic carbon export fluxes in the Canada Basin and Bering Sea as derived from ${ }^{234} \mathrm{Th} /{ }^{238} \mathrm{U}$ disequilibria. Arctic 56:32-44

Chivasa S, Tome DFA, Hamilton JM, Slabas AR (2011) Proteomic analysis of extracellular ATP-regulated proteins identifies ATP synthase beta-subunit as a novel plant cell death regulator. Mol Cell Proteomics 10:M110.003905

> Choi HW, Kim YJ, Hwang BK (2011) The hypersensitive induced reaction and leucine-rich repeat proteins regulate plant cell death associated with disease and plant immunity. Mol Plant Microbe Interact 24:68-78

Codispoti LA (2007) An oceanic fixed nitrogen sink exceeding $400 \mathrm{Tg} \mathrm{N} \mathrm{a}{ }^{-1}$ vs the concept of homeostasis in the fixed-nitrogen inventory. Biogeosciences 4:233-253

Collins MJ, Westbroek P, Muyzer G, Deleeuw JW (1992) Experimental-evidence for condensation-reactions between sugars and proteins in carbonate skeletons. Geochim Cosmochim Acta 56:1539-1544

Cowie GL, Hedges JI (1992) Sources and reactivities of amino acids in a coastal marine environment. Limnol Oceanogr 37:703-724

> Cowie GL, Hedges JI (1994) Biochemical indicators of diagenetic alteration in natural organic matter mixtures. Nature 369:304-307

Deutsch C, Sigman DM, Thunell RC, Meckler AN, Haug GH (2004) Isotopic constraints on glacial/interglacial changes in the oceanic nitrogen budget. Global Biogeochem Cycles 18:GB4012

Drapeau GR, Boily Y, Houmard J (1972) Purification and properties of an extracellular protease of Staphylococcus aureus. J Biol Chem 247:6720-6726

Eng JK, McCormack AL, Yates JR (1994) An approach to correlate tandem mass spectral data of peptides with amino-acid-sequences in a protein database. J Am Soc Mass Spectrom 5:976-989

> Eng JK, Fischer B, Grossmann J, MacCoss MJ (2008) A fast SEQUEST cross correlation algorithm. J Proteome Res 7: 4598-4602

Granger J, Prokopenko MG, Sigman DM, Mordy CW and others (2011) Coupled nitrification-denitrification in sediment of the eastern Bering Sea shelf leads to ${ }^{15} \mathrm{~N}$ enrichment of fixed $\mathrm{N}$ in shelf waters. J Geophys Res 116: C11006, doi:10.1029/2010JC006751

Grebmeier JM, McRoy CP, Feder HM (1988) Pelagic-benthic coupling on the shelf of the Northern Bering and 
Chukchi Seas. 1. Food supply source and benthic biomass. Mar Ecol Prog Ser 48:57-67

Großkopf T, Mohr W, Baustian T, Schunck H and others (2012) Doubling of marine dinitrogen-fixation rates based on direct measurements. Nature 488:361-364

Harvey HR, Tuttle JH, Bell JT (1995) Kinetics of phytoplankton decay during simulated sedimentation: changes in biochemical composition and microbial activity under oxic and anoxic conditions. Geochim Cosmochim Acta 59:3367-3377

Horak REA, Whitney H, Shull DH, Mordy CW, Devol AH (2013) The role of sediments on the Bering Sea shelf $N$ cycle: insights from measurements of benthic denitrification and benthic DIN fluxes. Deep-Sea Res II 94:95-105

> Jamers A, Blust R, De Coen W (2009) Omics in algae: paving the way for a systems biological understanding of algal stress phenomena? Aquat Toxicol 92:114-121

> Keller A, Nesvizhskii AI, Kolker E, Aebersold R (2002) Empirical statistical model to estimate the accuracy of peptide identifications made by MS/MS and database search. Anal Chem 74:5383-5392

Kim HY, Kim K (2003) Protein glycation inhibitory and antioxidative activities of some plant extracts in vitro. J Agric Food Chem 51:1586-1591

> Lee C, Wakeham SG, Hedges JI (2000) Composition and flux of particulate amino acids and chloropigments in equatorial Pacific seawater and sediments. Deep-Sea Res I 47:1535-1568

Lomas MW, Moran SB, Casey JR, Bell DW and others (2012) Spatial and seasonal variability of primary production on the Eastern Bering Sea shelf. Deep-Sea Res II 65-70: 126-140

> Lovvorn JR, Cooper LW, Brooks ML, De Ruyck CC, Bump JK, Grebmeier JM (2005) Organic matter pathways to zooplankton and benthos under pack ice in late winter and open water in late summer in the north-central Bering Sea. Mar Ecol Prog Ser 291:135-150

> Mahaffey C, Michaels AF, Capone DG (2005) The conundrum of marine $\mathrm{N}_{2}$ fixation. Am J Sci 305:546-595

Maley F, Trimble RB, Tarentino AL, Plummer TH Jr (1989) Characterization of glycoproteins and their associated oligosaccharides through the use of endoglycosidases. Anal Biochem 180:195-204

McCarthy M, Pratum T, Hedges J, Benner R (1997) Chemical composition of dissolved organic nitrogen in the ocean. Nature 390:150-154

McRoy CP, Hansell DA, Springer AM, Walsh JJ, Whitledge TE (1987) Global maximum of primary production in the North Bering Sea. Eos 68:L1727

> Moore EK, Nunn BL, Goodlett DR, Harvey HR (2012a) Identifying and tracking proteins through the marine water column: insights into the inputs and preservation mechanisms of protein in sediments. Geochim Cosmochim Acta 83:324-359

Moore EK, Nunn BL, Faux JF, Goodlett DR, Harvey HR (2012b) Evaluation of electrophoretic protein extraction and database-driven protein identification from marine sediments. Limnol Oceanogr Methods 10:353-366

Moran SB, Lomas MW, Kelly RP, Gradinger R, Iken K, Mathis JT (2012) Seasonal succession of net primary productivity, particulate organic carbon export, and autotrophic community composition in the eastern Bering Sea. Deep-Sea Res II 65-70:84-97

> Nesvizhskii AI, Keller A, Kolker E, Aebersold R (2003) A statistical model for identifying proteins by tandem mass spectrometry. Anal Chem 75:4646-4658

Nguyen RT, Harvey HR (2001) Protein preservation in marine systems: hydrophobic and other non-covalent associations as major stabilizing forces. Geochim Cosmochim Acta 65:1467-1480

Nguyen RT, Harvey HR, Zang X, van Heemst JDH, Hetenyi M, Hatcher PG (2003) Preservation of algaenan and proteinaceous material during the oxic decay of Botryococcus braunii as revealed by pyrolysis-gas chromatography/mass spectrometry and ${ }^{13} \mathrm{C}$ NMR spectroscopy. Org Geochem 34:483-497

> Nunn BL, Shaffer SA, Scherl A, Gallis B, Wu M, Miller SI, Goodlett DR (2006) Comparison of a Salmonella typhimurium proteome defined by shotgun proteomics directly on an LTQ-FT and by proteome pre-fractionation on an LCQ-DUO. Brief Funct Genomics Proteomics $5: 154-168$

Nunn BL, Ting YS, Malmstroem L, Tsai YS, Squier A, Goodlett DR, Harvey HR (2010) The path to preservation: using proteomics to decipher the fate of diatom proteins during microbial degradation. Limnol Oceanogr 55: 1790-1804

Pantoja S, Lee C (1999) Molecular weight distribution of proteinaceous material in Long Island Sound sediments. Limnol Oceanogr 44:1323-1330

Peters E, Thomas DN (1996) Prolonged darkness and diatom mortality I. Marine Antarctic species. J Exp Mar Biol Ecol 207:25-41

Plummer TH, Elder JH, Alexander S, Phelant AW, Tarentino AL (1984) Demonstration of peptide:N-glycosidase F activity in endo-beta- $\mathrm{N}$-acetylglucosaminidase $\mathrm{F}$ preparations. J Biol Chem 259:10700-10704

Sambrotto RN, Niebauer HJ, Goering JJ, Iverson RL (1986) Relationships among verticle mixing, nitrate uptake, and phytoplankton growth during spring bloom in the southeast Bering Sea. Cont Shelf Res 5:161-198

> Silvestre F, Gillardin V, Dorts J (2012) Proteomics to assess the role of phenotypic plasticity in aquatic organisms exposed to pollution and global warming. Integr Comp Biol 52:681-694

Smetacek VS (1985) Role of sinking in diatom life-history cycles: ecological, evolutionary, and geological significance. Mar Biol 84:239-251

Springer AM, McRoy CP, Flint MV (1996) The Bering Sea Green Belt: shelf-edge processes and ecosystem production. Fish Oceanogr 5:205-223

Steward GF, Smith DC, Azam F (1996) Abundance and production of bacteria and viruses in the Bering and Chukchi Seas. Mar Ecol Prog Ser 131:287-300

Sultana N, Choudhary MI, Khan A (2009) Protein glycation inhibitory activities of Lawsonia inermis and its active principles. J Enzyme Inhib Med Chem 24:257-261

> Sun Z, Liu J, Zeng X, Huangfu J, Jiang Y, Wang M, Chen F (2011) Astaxanthin is responsible for antiglycoxidative properties of microalga Chlorella zofingiensis. Food Chem 126:1629-1635

Tanner S, Shu HJ, Frank A, Wang LC and others (2005) InsPecT: identification of posttranslationally modified peptides from tandem mass spectra. Anal Chem 77: 4626-4639

- Vaque D, Guadayol O, Peters F, Felipe J and others (2008) Seasonal changes in planktonic bacterivory rates under the ice-covered coastal Arctic Ocean. Limnol Oceanogr 53:2427-2438

Vetter YA, Deming TW (1999) Growth rates of marine bacte- 
rial isolates on particulate organic substrates solubilized by freely released extracellular enzymes. Microb Ecol 37:86-94

Waldhier MC, Dettmer K, Gruber MA, Oefner PJ (2010) Comparison of derivatization and chromatographic methods for GC-MS analysis of amino acid enantiomers in physiological samples. J Chromatogr B 878:1103-1112

Wiese FK, Wiseman Jr. WJ, Van Pelt TI (2012) Bering Sea linkages. Deep-Sea Res II 65-70:2-5

Yamauchi Y, Ejiri Y, Tanaka K (2002) Glycation by ascorbic acid causes loss of activity of ribulose-1,5-bisphosphate carboxylase/oxygenase and its increased susceptibility to proteases. Plant Cell Physiol 43:1334-1341
Yi EC, Marelli M, Lee H, Purvine SO, Aebersold R, Aitchison JD, Goodlett DR (2002) Approaching complete peroxisome characterization by gas-phase fractionation. Electrophoresis 23:3205-3216

Zang X, Nguyen RT, Harvey HR, Knicker H, Hatcher PG (2001) Preservation of proteinaceous material during the degradation of the green alga Botryococcus braunii: a solid-state $2 \mathrm{D}{ }^{15} \mathrm{~N}^{13} \mathrm{C}$ NMR spectroscopy study. Geochim Cosmochim Acta 65:3299-3305

Zubkov MV, Fuchs BM, Eilers H, Burkill PH, Amann R (1999) Determination of total protein content of bacterial cells by SYPRO staining and flow cytometry. Appl Environ Microbiol 65:3251-3257

Appendix 1. Amino acid distribution (mole \%) of phytoplankton derived particulate material from each time point of $11 \mathrm{~d}$ and $53 \mathrm{~d}$ shipboard incubations of phytoplankton collected from the Bering Sea. Values are means with standard error in parentheses.

\begin{tabular}{|c|c|c|c|c|c|c|c|c|}
\hline \multirow{2}{*}{$11 \mathrm{~d}$ incubation } & \multicolumn{8}{|c|}{-Day } \\
\hline & 0 & 0.5 & 1 & 3 & 5 & 7 & 9 & 11 \\
\hline Alanine & $14.92(0.33)$ & $9.80(0.18)$ & $9.63(0.12)$ & $8.55(0.46)$ & $8.52(0.17)$ & $9.48(0.06)$ & $10.08(0.77)$ & $9.60(0.16)$ \\
\hline Glycine & $7.37(0.09)$ & $7.83(0.05)$ & $8.35(0.13)$ & $8.42(0.13)$ & $8.30(0.19)$ & $8.96(0.12)$ & $8.86(0.17)$ & $9.48(0.11)$ \\
\hline Valine & $6.93(0.33)$ & $5.42(0.11)$ & $5.37(0.08)$ & $5.84(0.15)$ & $5.69(0.08)$ & $5.83(0.10)$ & $5.55(0.08)$ & $5.74(0.12)$ \\
\hline Leucine & $6.56(0.17)$ & $6.32(0.05)$ & $6.59(0.01)$ & $6.64(0.09)$ & $6.48(0.10)$ & $6.83(0.04)$ & $6.69(0.01)$ & $6.62(0.09)$ \\
\hline Isoleucine & $4.35(0.16)$ & $4.60(0.05)$ & $4.49(0.30)$ & $4.98(0.10)$ & $4.65(0.21)$ & $4.35(0.06)$ & $4.11(0.16)$ & $4.30(0.03)$ \\
\hline Threonine & $3.66(0.25)$ & $7.87(0.54)$ & $7.29(0.30)$ & $7.43(0.35)$ & $8.35(0.42)$ & $5.93(0.14)$ & $5.59(0.32)$ & $6.06(0.04)$ \\
\hline Proline & $4.42(0.09)$ & $4.17(0.03)$ & $4.22(0.02)$ & $3.81(0.04)$ & $3.58(0.10)$ & $4.34(0.12)$ & $4.21(0.03)$ & $4.16(0.07)$ \\
\hline Aspartic acid/asparagine & $5.56(0.24)$ & $9.53(0.13)$ & $9.53(0.10)$ & $10.25(0.30)$ & $10.07(0.25)$ & $9.45(0.05)$ & $9.37(0.28)$ & $9.37(0.15)$ \\
\hline Phenylalanine & $2.33(0.04)$ & $3.13(0.06)$ & $3.32(0.01)$ & $3.69(0.13)$ & $3.49(0.08)$ & $3.27(0.06)$ & $3.26(0.02)$ & $3.25(0.11)$ \\
\hline Glutamic acid/glutamine & $10.18(1.40)$ & $12.32(1.01)$ & $11(0.16)$ & $10.47(0.17)$ & $12.22(0.59)$ & $10.21(0.87)$ & $11.01(1.22)$ & $10.31(0.97)$ \\
\hline Lysine & $3.94(0.72)$ & $3.18(0.12)$ & $3.21(0.11)$ & $3.45(0.08)$ & $4.53(0.31)$ & $2.94(0.38)$ & $3.46(0.27)$ & $2.81(0.47)$ \\
\hline Tyrosine & $3.65(1.92)$ & $1.99(0.25)$ & $1.22(0.03)$ & $1.16(0.13)$ & $2.28(0.14)$ & $0.68(0.18)$ & $0.91(0.13)$ & $0.70(0.07)$ \\
\hline \multirow{2}{*}{$53 \mathrm{~d}$ incubation } & \multicolumn{8}{|c|}{ - Day } \\
\hline & 0 & 5 & 12 & 22 & 35 & 47 & 53 & \\
\hline Alanine & $17.93(1.79)$ & $15.30(0.51)$ & $15.75(1.52)$ & $12.87(0.70)$ & $15.43(0.27)$ & $15.45(0.16)$ & $15.30(0.72)$ & \\
\hline Glycine & $13.57(0.16)$ & $13.24(0.55)$ & $15.99(2.47)$ & $11.62(0.51)$ & $15.37(0.72)$ & $16.90(0.29)$ & $17.14(0.63)$ & \\
\hline Valine & $6.18(0.44)$ & $6.91(0.39)$ & $5.96(0.63)$ & $7.72(0.25)$ & $10.68(0.68)$ & $11.66(0.03)$ & $11.26(0.76)$ & \\
\hline Leucine & $9.12(0.35)$ & $9.26(0.60)$ & $9.24(0.92)$ & $7.81(0.32)$ & $9.21(0.44)$ & $9.80(0.18)$ & $9.26(0.58)$ & \\
\hline Isoleucine & $4.37(0.13)$ & $3.56(0.23)$ & $4.23(0.19)$ & $4.28(0.12)$ & $3.89(0.03)$ & $3.72(0.16)$ & $3.53(0.22)$ & \\
\hline Threonine & $3.42(0.44)$ & $4.18(0.49)$ & $4.75(0.67)$ & $7.21(0.39)$ & $6.70(0.74)$ & $6.79(0.48)$ & $6.99(1.44)$ & \\
\hline Proline & $6.04(0.62)$ & $5.99(0.20)$ & $7.06(1.57)$ & $4.51(0.08)$ & $3.02(0.49)$ & $2.62(0.27)$ & $3.13(0.55)$ & \\
\hline Aspartic acid/asparagine & $10.18(0.88)$ & $10.48(0.46)$ & $11.39(0.95)$ & $10.18(0.59)$ & $4.97(0.98)$ & $4.88(0.86)$ & $7.41(2.08)$ & \\
\hline Phenylalanine & $3.69(0.41)$ & $3.46(0.28)$ & $3.96(0.12)$ & $4.16(0.10)$ & $5.31(0.21)$ & $5.32(0.33)$ & $4.98(0.13)$ & \\
\hline Glutamic acid/glutamine & $12.74(0.57)$ & $14.34(0.80)$ & $13.63(3.72)$ & $19.57(1.41)$ & $12.16(0.96)$ & $10.61(0.77)$ & $10.11(0.28)$ & \\
\hline Lysine & $5.43(0.57)$ & $5.88(0.44)$ & $4.18(1.18)$ & $5.11(0.18)$ & $5.48(0.71)$ & $4.54(0.65)$ & $3.63(0.64)$ & \\
\hline Tyrosine & $7.47(0.35)$ & $7.41(3.37)$ & $3.87(1.54)$ & $4.99(0.38)$ & $7.78(0.56)$ & 7.69 (1.52) & $7.27(0.95)$ & \\
\hline
\end{tabular}

Editorial responsibility: Steven Lohrenz, New Bedford, Massachusetts, USA
Submitted: November 11, 2013; Accepted: July 9, 2014 Proofs received from author(s): October 27, 2014 